\title{
Peran Ragam Hias Tradisional Melayu Riau pada Desain Produk Kerajinan Kayu di Pekanbaru
}

\author{
Bambang Sungkowo \\ Universitas Negeri Padang
}

\begin{abstract}
Melayu Riau uses many wooden craft products, ranging from casings for rituals to varieties of souvenirs. As similar to other areas of Indonesia, Melayu Riau community possesses various decorative styles that are rich in motifs and laden with meanings. It is an endless potential source for wooden craftsmen, yet not many have optimally exploited them. This study observes wooden crafts of Melayu Riau in Pekanbaru (especially souvenirs), in order to expose the roles of traditional decorative styles of Melayu, their ridden symbolic meanings, and the possibility of using them as sources for creating various wooden craft products. To address the purpose, the study applied descriptive approach using interviews, document study, and observation as means of data collecting. Results of analysis showed that newly created wooden products from the Center of Melayu Riau Souvenirs support varieties of functions yet their aesthetic qualities are not representatively qualified. Too many products repeatedly use floral and nail kaluk motifs, as if there are no other available motifs. Thus, the products look monotonous in shapes, colors, and applied decorative elements. To make the products representatively qualified, it is better to address the aesthetic qualities of the product by exploiting varieties of motifs, alternate colors, shapes, and decorative elements.
\end{abstract}

Keywords: craft products; Melayu Riau; ornaments.

\section{Pendahuluan}

Sesuai letak geografis yang cukup strategis, kota Pekanbaru memiliki peran sebagai kota transit yang menghubungkan kota-kota besar di Sumatera. Sebagai daerah transit dengan beberapa fasilitasnya berupa pelabuhan udara, pelabuhan sungai, terminal serta fasilitas wisata dan rekreasi yang memadai, kota Pekanbaru banyak dikunjungi oleh wisatawan baik dari luar maupun dalam negeri yang ingin melanjutkan perjalanannya ke daerah lain di Sumatera seperti Medan, Jambi, Padang, Batam dan Malaysia.

Kondisi tersebut dimanfaatkan oleh perajin sebagai peluang usaha untuk menyediakan produk-produk kerajinan fungsional, dan cinderamata khas dari Pekanbaru. Hal ini sejalan dengan anjuran dari walikota Pekanbaru melalui Disperindag Kota selaku instansi yang bertanggung jawab terhadap pembinaan Industri Kecil dan Menengah (IKM) kepada perajin bahwa, setiap jenis produk 
kerajinan baik produk kayu, tekstil maupun logam yang diproduksi di Pekanbaru harus memiliki ciri khas Melayu Riau sebagai identitas produk. Anjuran tersebut dipertegas dalam misi kota Pekanbaru antara lain yaitu: melestarikan, membina dan mengembangkan kebudayaan Melayu yang mampu mengikuti perkembangan zaman dengan tetap mempertahankan jati diri [1].

Berdasarkan uraian di atas salah satu hasil produk budaya masyarakat Melayu Riau yang perlu dilestarikan dan dikembangkan dalam konteks kerajinan adalah seni ragam hias tradisional pada produk kerajinan kayu, khususnya pada produk pewadahan untuk keperluan upacara adat dan bukan untuk keperluan adat sebagai cinderamata yang pada saat ini jumlahnya semakin berkurang.

Masyarakat Melayu Riau memiliki bermacam jenis dan bentuk ragam hias (ukiran kayu) yang sudah berkembang sejak ratusan tahun silam, tetapi potensi tersebut baru dimanfaatkan sebagai unsur dekorasi pada kerajinan tekstil dan bangunan, sedangkan pada produk kerajinan kayu seperti wadah untuk keperluan upacara adat belum dimanfaatkan secara optimal oleh perajin, akibatnya produk wadah untuk keperluan upacara adat yang ada sekarang ini sangat minim dengan ragam hias. Kondisi tersebut akibat dari kurangnya pemanfaatan ragam hias sebagai sumber kreatifitas dalam melakukan diversifikasi produk kerajinan. Diversifikasi produk dalam hal ini bertujuan untuk menghasilkan produk kerajinan yang bervariasi dalam penggunaan ragam hias dalam tujuan meningkatkan volume penjualan. Diversifikasi produk dilakukan mengingat kemungkinan terjadinya kejenuhan konsumen terhadap produk yang ditawarkan yang mengakibatkan menurunya daya beli. Maksud difersifikasi produk dalam konteks ini yaitu peran ragam hias tradisional sebagai dekorasi produk kerajinan yang ditempatkan dengan berbagai cara atau pola penempatan sehingga menghasilkan satu jenis produk dengan bermacammacam ragam hias.

Penempatan ragam hias umumnya karena permintaan konsumen, tanpa memperhatikan benar atau salah menurut makna simbolik ragam hias, seperti ragam hias naga berjuang sebagai simbol kepahlawanan dan kekuasaan para pembesar kerajaan, dalam penggunaan hanya diperbolehkan untuk lingkungan kerajaan, ternyata sekarang diterapkan untuk dekorasi pada kotak serbaguna dan benda fungsional. Penerapan ragam hias tersebut sangat bertentangan dengan aturan penempatan ragam hias, tetapi dapat meningkatkan ekonomi perajin tidak dipermasalahkan.

Peran ragam hias pada produk kerajinan, secara visual adalah untuk menambah nilai keindahan (estetis) suatu bentuk produk dimana ragam hias tersebut ditempatkan agar lebih menarik dan berguna [2]. Hal ini sejalan dengan yang diungkapkan oleh Kenji Ekuan yang dikutip dalam buku Eddy 
Marizar, bahwa manusia membutuhkan/merindukan keindahan dari setiap benda pakainya [3]. Tetapi selain sebagai unsur dekorasi pada produk kerajinan, peran ragam hias bertujuan untuk menghasilkan produk kerajinan kayu yang memiliki ciri khas dalam rangka untuk menaikkan citra daerah. Maksud menaikan citra daerah dalam konteks ini adalah bahwa peran ragam hias tradisional pada produk kerajinan yang dihasilkan harus mengekspresikan nilainilai tradisi kesenian Melayu Riau, yaitu melalui seni dekorasi. Setiap ragam hias tradisional menurut pandangan masyarakat Melayu Riau memiliki arti dan perlambang yang nilainya mengacu pada sifat-sifat benda atau mahkluk yang dijadikan corak, dipadukan dengan nilai kepercayaan, nilai budaya daerah dan nilai-nilai luhur agama Islam yang dianutnya.

\section{$2 \quad$ Metodologi}

Peran ragam hias tradisional Melayu pada produk kerajinan kayu pada dasarnya bertujuan untuk menjadikan produk tampil lebih indah dan menarik, sehingga memberi pengaruh terhadap harga jual produk. Dalam hal ini terjadi adanya perubahan peran ragam hias tradisional yang diterapkan pada produk kerajinan kayu kearah budaya sekuler, dengan demikian dikhawatirkan peran ragam hias tradisional pada produk kerajinan kayu, terutama pada jenis produk pewadahan untuk keperluan upacara adat tidak lagi memiliki makna simbolik, tetapi lebih mengutamakan nilai estetis untuk tujuan ekonomi semata [4].

Sehubungan dengan hal tersebut di atas perlu dilakukan penelitian yang lebih dalam tentang peran ragam hias tradisional yang terdapat pada produk wadah untuk keperluan upacara adat yang meliputi : peran ragam hias dalam perspektif makna simbolik dan peran ragam hias sebagai pengusung nilai estetis untuk meningkatkan varian produk. Detail proses kerja penelitianm dipaparkan dalam Gambar 1.

Pada karya-karya seni tradisional Melayu, khususnya produk kerajinan kayu yang menggunakan unsur-unsur ragam hias sebagai kekuatan ekspresinya, tidak seluruhnya memiliki kandungan makna. Banyak diantara produk kerajinan kayu terutama produk wadah yang ada pada saat ini yang menggunakan ragam hias hanya berfungsi sebagai elemen dekorasi semata.

Berdasarkan hasil identifikasi pada produk kerajinan perwadahan upacara adat, menunjukkan adanya gejala perubahan peran ragam hias yang mengarah pada budaya massa. Seperti yang terjadi pada Sentra Melayu Riau Souvenir, keberadaan aktifitasnya cenderung menunjukkan pertumbuhan aktifitas berkarya berdasarkan pada nilai ekonomi. Pertumbuhan dan produktifitas berkarya dari para perupanya tidak lagi didasarkan pada pertimbangan spiritual seperti yang pernah dilakukan para perupa pada zaman kerajaan Siak [4]. 
Tradisi kesenian lama yang kaya dengan makna, telah putus dengan adanya perubahan orientasi pandangan hidup. Ekspresi keseniannya tidak lagi mengandung makna simbolik dan nilai estetis yang berdasarkan pada bentuk aslinya, akan tetapi cenderung mengutamakan kondisi pasar.

\section{Gambaran Umum Industri Kerajinan Kayu di Pekanbaru}

Industri kerajinan kayu di Pekanbaru dewasa ini termasuk salah satu industri yang dijadikan sebagai penopang hidup rakyat khususnya bagi mereka yang memiliki keterampilan menengah. Industri kerajinan kayu yang paling banyak menyerap tenaga kerja adalah industri mebel, kusen dan daun pintu/jendela sedangkan untuk handy craft jumlahnya masih sedikit.

Pada 1993 perkembangan industri kayu di Pekanbaru menunjukan peningkatan yang sangat pesat. Banyak berdiri industri baru di sepanjang jalan Arengka I dan Jalan Subrantas/Panam-Pekanbaru. Salah faktor pendorong dari muncul industi kayu ketika itu adalah, terkait dengan akan dilaksanakannya Musabaqoh Tilawatil Quran (MTQ) tingkat nasional pada tahun 1994, dimana dalam areal MTQ tersebut akan dibangunan rumah adat dari seluruh kabupaten yang ada dipropinsi Riau dengan hiasan ornamen ukiran Melayu Riau. Oleh karena itu produk kerajinan ukiran kayu sangat dibutuhkan, sehingga bengkel-bengkel ukiran seperti Kurnia Jaya, Saeniki, Singa 81 dan Anton Selembayung banyak menerima order ukiran dengan harga yang cukup tinggi, akibatnya upah mengukir ketika itu ditentukan oleh tukang ukir sendiri. Pada watu itulah awal perkembangan industri kerajinan kayu khususnya ukiran mulai di masyarakatkan kembali setelah beberapa tahun sebelumya ditinggalkan oleh masyarakat, hingga mencapai kejayaannya sampai sekarang ini.

Kerajinan kayu yang berkembang dari masa kemasa tidak terlepas dari masyarakat pendukungnya (produsen dan konsumen). Berbagai pergeseran yang terjadi selalu bertolak dari tujuan pembuatan produk kerajinan itu sendiri.

Namun dalam beberapa tahun terakhir, geliat para perajin mulai menurun akibat kondisi perekonomian yang tidak menguntungkan. Kenaikan BBM tahun lalu sangat memukul mereka. Selain kenaikan BBM maraknya penangkapan kayu ilegal berakibat semakin sulit dan mahalnya harga bahan baku, akibatnya biaya produksi menjadi tinggi. Mengingat kebutuhan masyarakat di Pekanbaru dan Propinsi Riau pada umumnya terhadap produk kerajinan kayu masih cukup tinggi, beberapa perajin khususnya mebel mengalihkan usahanya sebagai finishing barang setengah jadi, menjadi barang jadi, terutama perajin yang berasal dari jepara. Mereka membeli mebel dari Jepara setengah jadi kemudian di-finishing di Pekanbaru dan hasilnya secara ekonomi sangat menguntungkan. 
Jadi wajar saja jika seluruh show room yang ada di Pekanbaru semuanya menjual mebel produk Jepara.

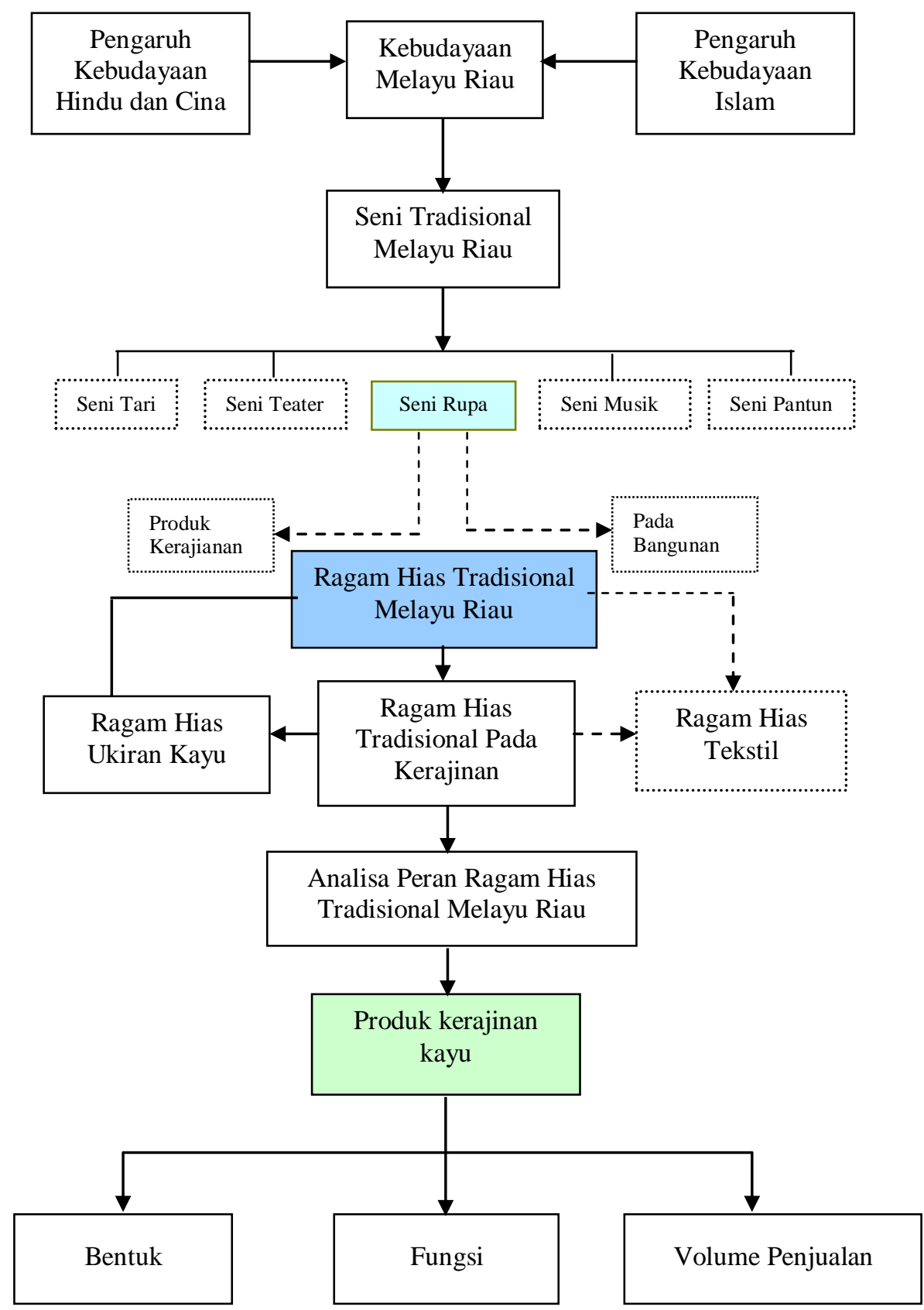

Gambar 1 Bagan Kerja Penelitian. 
Selain produk perabot rumah tangga (mebel) jenis produk lain yang ada di Pekanbaru adalah kerajinan kayu (handycraft) khususnya produk wadah untuk keperluan upacara adat dan cinderamata. Pada mulanya produk kerajinan tersebut hanya berfungsi sebagai benda keperluan adat atau fungsi sakral. Kerajinan dibuat oleh satu orang. Tetapi kini produk tersebut sudah mempunyai fungsi sekular, sebagai benda pakai sehari-hari yang jumlahnya jauh lebih besar daripada fungsi spiritual. Kerajinan sudah mendapat tempat di hati masyarakat luas, sehingga dijual secara luas dan mempunyai fungsi ekonomi yang berarti. Produk wadah untuk keperluan upacara adat dan cinderamata yang memiliki ciri khas Melayu Riau saat ini mempunyai prospek pasar cukup bagus, mengingat kebutuhan akan produk wadah dan cinderamata Melayu Riau sangat tinggi. Ini terbukti dari permintaan Dekranasda Propinsi Riau terhadap produk kerajinan kayu khas Melayu Riau [5].

Dalam perkembangannya industri kerajinan kayu di Pekanbaru juga mengalami pasang surut, ini disebabkan dari berbagai faktor antara lain desain produk yang kurang baik. Kurang disini dalam arti bahwa desain tidak mengalami perkembangan sesuai dengan perjalanan waktu, akibatanya produk bersifat monoton dan tidak bervariatif. Inilah permasalahan mendasar yang dihadapi oleh perajin di kota Pekanbaru pada masa sekarang ini yang segera dicarikan solusi pemecahannya.

\section{$4 \quad$ Kebijakan Pemerintah Kota Pekanbaru dalam Mengembangkan Industri Kecil dan Menengah}

Kebijakan utama pemerintah kota Pekanbaru dalam program pemberdayaan industri kecil dan kerajinan adalah melakukan pengembangan industri kecil dan menengah termasuk industri tradisional dan industri rumah tangga untuk dijadikan kekuatan dan penggerak utama pembangunan ekonomi, dengan mengadakan program pembinaan usaha dan kemampuan bagi para perajin. Program peningkatan sistem pembinaan dan kemampuan bagi perajin dalam penguasaan teknologi. Relokasi industri (penyediaan lahan kawasan industri yang terpadu), serta menciptakan sentra-sentra industri kecil menengah.

Sentra dapat diartikan sebagai suatu kosentrasi dari sekumpulan unit usaha yang sejenis di suatu lokasi yang sama. Unit usaha sejenis diartikan sebagai kesamaan berdasarkan pada jenis barang yang iproduksi, kesamaan dari bahan/material yang digunakan. Dalam hal ini pemerintah kota Pekanbaru menetapkan daerah industri kerajinan kayu terkosentrasi di Kecamatan Tampan, sedangkan kerijinan rotan terkosentrasi di Kecamatan Rumbai. Dengan terkonsentrasinya unit-unit usaha dalam suatu sentra: 
1. Secara tidak langsung dapat menciptakan skala ekonomi yang lebih tinggi dibandingkan jika kegiatan usaha dilakukan oleh masing-masing unit usaha.

2. Akan menciptakan persaingan sehat berdasarkan faktor komparatif dan indikator kolektif terhadap unit-unit usaha lainnya untuk menjaga dan meningkatkan kualitas produk, menjaga kestabilan nilai tawar produk padakonsumen.

3. Dapat memudahkan calon konsumen ketika mencari industri kerajinan terkait untuk memenuhi kebuhan produk-produknya, karena keberadaan sentra relatif lebih mudah dicari.

4. Memudahkan dalam melakukan berbagai koordinasi berkaitan dengan berbagai permasalahan yang terkait dengan usahanya.

Disamping penetapan daerah sentra industri kerajinan, pemerintah kota Pekanbaru tetap konsen terhadap perkembangan dan kemajuan indutri kecil. Hal ini dibuktikan dengan diselenggarakannya berbagai pelatihan baik pelatihan manajemen pengelolaan usaha, peningkatan keterampilan, pameran, serta pemberian bantuan peralatan dan modal usaha. Tetapi program ini tidak semuanya berhasil mengingat karakter dan mentalitas dari masing-masing perajin berbeda-beda. Disamping itu program pelatihan dan pasca pelatihan yang belum mendapat perhatian serius dari pihak terkait sehingga perajin menganggap pogram pelatihan dan bantuan yang mereka dapatkan merupakan hadiah belaka. Itulah sebabnya setiap program pelatihan yang diselenggarakan tingkat keberhasilannya sangat kecil sekali.

\section{$5 \quad$ Tinjauan Permasalahan yang Dihadapi Perajin Kayu di Pekanbaru}

Secara garis besar permasalahan yang dihadapi perajin kayu di Pekanbaru terdiri dari empat kelompok yaitu:

\subsection{Organisasi dan Manajemen}

Berbagai tuntutan pasar hanya dapat dipenuhi jika perajin mengelola produksinya berdasarkan pola produksi industri kerajinan. Termasuk didalamnya penerapan manajemen industri agar mampu melaksanakan sistem kerja yang profesional untuk mendukung produksi industri kerajinan yang berorientasi pada standar ekspor [6].

Dalam kaitan ini pola manajemen yang sesuai dengan kebutuhan dan tahap perkembangan usaha sulit ditemukan, antara lain karena pengetahuan perajin relatif rendah, akibatnya perajin belum mampu menyusun starategi bisnis yang tepat. Pemisahan antara manajemen keuangan dan keluarga atau rumah tangga 
belum dilakukan, sehingga perajin mengalami kesulitan dalam mengontrol dan membuat perencanaan kedepan.

Kemampuan perajin dalam mengorganisasikan diri dan karyawan masih lemah, sehingga terjadi pembagian kerja yang tidak jelas dan seringkali pengusaha harus bertindak sendiri. Pelatihan tentang majemen dari instansi terkait selama ini belum memberikan pengaruh yang berarti terhadap kemajuan, ini disebabkan materi yang diberikan tidak sesuai dengan kebutuhan, serta tidak ada kegiatan pendampingan setelah pasca pelatihan..

\section{$5.2 \quad$ Sistim Pemasaran}

Pemasaran produk kerajinan dilakukan dengan cara titip jual, melalui hubungan sesama rekan dan konsumen datang langsung ke perajin. Untuk jenis usaha kecil, seseorang mungkin dapat menangani semua tugas pemasaran, penjualan, pelayanan terhadap pelanggan, dan sebagainya, tetapi untuk pengembangan kedepan pola seperti ini akan jauh tertinggal. Kita perlu infomasi tentang perkembangn pasar, pelung pasar, produk yang diminati konsumen dan sebagainanya.

Uraian diatas adalah kondisi nyata yang ditemukan di lapangan yang merupakan permasalahan di hadapi perajin dibidang pemasaran produk kerajinan kayu. Kendala tersebut disebabkan kurangnya informasi untuk memasarkan produk, baik melalui media cetak berupa pemasangan iklan, pembuatan brosur, ataupun memanfaatkan obyek-obyek wisata, dan melalui media elektronik diantaranya jenis produk yang akan dipasarkan belum bisa diakses melalui jaringan internet. Akibatnya perajin tidak menjual produknya secara langsung tetapi melalui perantara dengan sistim konsinyasi (titip jual).

\section{$5.3 \quad$ Teknologi}

Teknologi dalam hal berkaitan mesin dan peralatan yang digunakan oleh industri Sentra Melayu Riau Souvenir dalam melakukan proses produksi. Peralatan dalam proses produksi merupakan keterpaduan antara kemampuan proses produksi dengan permintaan pasar. Peralatan memiliki peran yang sangat penting dalam kegiatan produksi, karena dengan peralatan yang lengkap dapat mempengaruhi biaya produksi. Dalam proses produksi teknologi yang digunakan memiliki peran cukup besar sehingga semakin baik kualitas teknologi yang digunakan, maka semakin banyak manfaat yang diperoleh diantaranya:

1. Proses produksi dapat dilakukan lebih cepat

2. Tenaga kerja yang digunakan lebih sedikit

3. Kualitas produk lebih maksimal 
Dalam kaitan ini industri kerajinan kayu di Pekanbaru sampai saat ini masih menggunakan peralatan yang multifungsi, artinya peralatan yang digunakan belum sesuai dengan kebutuhan, sehingga satu alat digunakan untuk bermacam jenis pekerjaan. Pada umumnya mereka menggunakan peralatan hasil rakitan sendiri sehingga tingkat akurasi ukuran sangat rendah. Ini tentunya disebabkan oleh terbatasnya modal perajin untuk pengadaan peralatan yang sesuai dengan standar kebutuhan.

\subsection{Masalah Desain}

Kegiatan usaha produksi kerajinan kayu khususnya produk wadah dan cinderamata, yang diproduksi oleh perajin di kota Pekanbaru, pada umumnya bukan desain dari perajin itu sendiri tetapi merupakan hasil tiruan dari produk lain. Dalam hal ini kreatifitas perajin dalam membuat desian belum dilakukan secara optimal. Desain masih dianggap sebagai hal yang kurang penting dalam kegiatan industri kerajinan. Sehingga yang terjadi di sentra-sentra industri kerajinan kayu di Pekanbaru pada saat ini jenis produk sangat terbatas dan kurang variatif serta memiliki bentuk yang sangat monoton (kaku).

Peran ragam hias sebagai unsur dekorasi pada produk belum dimanfaatkan secara optimal, sehingga banyak produk kerajinan yang dihasilkan pada saat ini sangat minim dengan ragam hias.

\section{Profil Perajin Sentra Melayu Riau Souvenir}

Sentra Melayu Riau Souvenir beralamat di jalan Purwodadi No 152 Kelurahan Sidomulyo Barat Kecamatan Tampan Panam Pekanbaru, merupakan industri kerajinan kayu yang memproduksi wadah untuk keperluan upacara adat dan cinderamata khas daerah Riau. Sentra Melayu Riau Souvenir memulai usahanya pada tahun 1997 dengan modal Rp 1.500.000. Produk yang dibuat pada waktu itu adalah cendramata berupa gantungan kunci, tepak sirih, kotak tisu dan perabot sekolah (hasil wawancara dengan perajin).

Dengan eksisnya dibidang produksi kerajinan kayu ini, sentra kerajinan kayu tersebut pernah mendapatkan pembinaan dari Dinas Perindustrian Kota Pekanbaru dan beberapa program pelatihan keterampilan. Program pelatihan yang pernah diikuti antara lain, tahun 1999 pelatihan peningkatan kualitas produk, tahun 2000 pelatihan pengembangan usaha, tahun 2002 pelatihan batik kayu di Yogyakarta dan terakhir tahun 2005 pelatihan peningkatan keterampilan.

Pimpinan Sentra Melayu Riau Souvenir bernama Adi Purnama, alumni IKIP Medan tahun 1992 jurusan teknik bangunan. Di bawah kendali Adipurnama, 
Sentra Melayu Riau Souvenir terus menata diri untuk selalu mengikuti perkembangan produk kerajinan yang diminati pasar. Berbagai terobosan telah dilakukan diantaranya melakukan kerjasama dengan dinas perindustrian, dinas pariwisata, dinas pendidikan dan pihak swasta seperti PT. RAPP dan beberapa industri kayu yang ada, terkait dengan pemanfaatan limbah kayu yang dihasilkan. Hal ini dapat kita lihat dari pembuangan limbah kayu jelutung, yang dibuang dengan percuma oleh pabrik.

Dalam perjalanannya industri kerajinan kayu yang masih tetap konsen terhadap pemanfaatan limbah kayu jelutung adalah Sentra Melayu Riau Cinderamata, $50 \%$ produknya memanfaatkan hasil limbah kayu jelutung dan kayu peti kemas mesin/alat berat terutama untuk produk cinderamata. Sedangkan untuk produk wadah dan benda multi fungsi menggunakan kayu balam, jelutung, sungkai dan rengas.

\subsection{Perkembangan Sentra Melayu Riau Souvenir}

Kegiatan industri kerajinan ini dimulai tahun 1997 dengan modal Rp 1.500.000,- yang digunakan untuk membeli peralatan dan bahan baku. Peralatan yang dibeli berupa 1 unit mesin Seckroll seharga Rp 650.000,- sedangkan bahan baku berupa kayu jelutung dan limbah bekas peti kemas alat berat yang dibeli di PT Trakindo.

Usaha ini pada awalnya merupakan kegiatan hobi Bapak Adi Purnama yang suka membuat kerajinan dari kayu. Dengan ketekunan dan ketabahan usaha ini mulai dikenal orang terutama di daerah lingkungan tempat tinggal pak Adi.

Dengan berjalannya waktu dan kejelian dalam membaca pasar, mulailah mendapatkan order pembuatan gantungan kunci untuk pesta perkawinan sebanyak 750 set. Kemudian pertengahan tahun 1998 mendapat orderan membuat produk kerajinan khas riau dari Disperindag Kota Pekanbaru dengan nilai Rp 1.300.000,- Dengan tenaga kerja yang sangat mengerti dengan kondisi perkembangan indutri, usaha ini terus menunujukan kemajuan dan lebih dikenal di Pekanbaru terutama Disperindag. Kesempatan ini dimanfaatkan oleh pak Adi dengan baik, sehingga awal tahun 2000 melalui wakil kepala Dinas Perindustrian dan perdagangan kota Pekanbaru Junaidi mengadakan kerjasama dibidang pembuatan produk kerajinan kayu khas Melayu Riau antara lain:

\section{Bidang Produk}

1. Berbagai jenis cinderamata khas Riau.

2. Produk wadah seperti baki, tempat buah, tempat koran/majalah

3. Produk wadah untuk keperluan upacara adat seperti, tepak sirih dan tabak

4. Produk bubutan kayu sungkai dengan berbagai model 
5. Produk ukiran untuk berbagai keperluan seperti untuk kedudukan fiting lampu gantung, ukiran untuk tiang, ukiran untuk tangga dan lain-lain

\section{Bidang Pemasaran Produk}

1. Membantu dalam memasarkan produk kerajinan dengan cara menyediakan fasilitas show room di jalam durian dan di perbatasan kota pekanbaru dengan kabupaten Kampar.

2. Mengisi stand pameran setiap diadakan pameran. Ini sudah menjadi agenda yang rutin dari Disperindag kota Pekanbaru.

Peluang ini dimanfaatkan oleh Sentra Melayu Riau Souvenir, sehingga pada pertengahan tahun 2003 dilakukan pembinaan dan pelatihan bagi 2 orang tenaga kerja untuk dilatih dan dimagangkan selama 2 bulan ke Yogyakarta dan terakhi tahun 2005 pelatihan mebel kayu kelapa di Pasuruan, Jawa Timur.

\subsection{Jenis Produk Kayu yan Dihasil Sentra Melayu Riau Souvenir}

Sentra Melayu Riau Cinderamata secara umum memproduksi berbagai macam jenis produk kerajinan khas Riau. Jenis kerajinan yang diproduksi pada dasarnya dikelompokkan menjadi tiga yaitu jenis produk untuk keperluan upacara adat, produk untuk cinderamata dan jenis produk untuk bangunan. Kelompok produk untuk keperluan upacara adat selalu menggunakan ragam hias sebagai dekorasi, sedangkan untuk keperluan cinderamata disesuaikan dengan permintaan konsumen.

Tabel 1 Spesifikasi Jenis Produk Wadah.

\begin{tabular}{|c|c|c|c|c|c|}
\hline No & Nama Produk & Fungsi Produk & $\begin{array}{c}\text { Ukuran } \\
(\mathbf{C m})\end{array}$ & Finishing & $\begin{array}{c}\text { Ragam } \\
\text { Hias }\end{array}$ \\
\hline 1. & & Tempat tisu & $\begin{array}{l}\mathrm{P}=25 \\
\mathrm{~L}=15 \\
\mathrm{~T}=12\end{array}$ & $\begin{array}{l}\text { Cat Impra } \\
\text { clear gloss } \\
\text { dan doop }\end{array}$ & A. Router \\
\hline 2. & & Tepak sirih & $\begin{aligned} \mathrm{P} & =30 / 24 \\
\mathrm{~L} & =24 / 14 \\
\mathrm{~T} & =15\end{aligned}$ & $\begin{array}{l}\text { Cat impra } \\
\text { clear gloss } \\
\text { dan doop }\end{array}$ & $\begin{array}{l}\text { Bunga } \\
\text { Cengkeh }\end{array}$ \\
\hline
\end{tabular}




\begin{tabular}{|c|c|c|c|c|c|}
\hline No & Nama Produk & Fungsi Produk & $\begin{array}{l}\text { Ukuran } \\
\text { (Cm) }\end{array}$ & Finishing & $\begin{array}{l}\text { Ragam } \\
\text { Hias }\end{array}$ \\
\hline 3. & & Kotak serbaguna & $\begin{array}{l}\mathrm{P}=40 \\
\mathrm{~L}=22 \\
\mathrm{~T}=15\end{array}$ & $\begin{array}{l}\text { Cat impra } \\
\text { clear gloss } \\
\text { dan doop }\end{array}$ & $\begin{array}{l}\text { A. } \\
\text { Motif Naga } \\
\text { berjuang } \\
\text { B. } \\
\text { Motif kaluk } \\
\text { paku }\end{array}$ \\
\hline 4. & & $\begin{array}{l}\text { Tabak Tempat } \\
\text { nasi } \\
\text { kuning }\end{array}$ & $\begin{array}{l}\text { A: } \\
P=20 \times \\
20 \times 10 \\
B: \\
P=25 \times \\
25 \times 10 \\
C: \\
P=30 \times \\
30 \times 10\end{array}$ & $\begin{array}{l}\text { Cat impra } \\
\text { dengan wood } \\
\text { stain tea } \\
\text { brown + clear } \\
\text { gloss dan } \\
\text { doop }\end{array}$ & $\begin{array}{l}\text { A, B, C } \\
\text { Motif lilit } \\
\text { kangkung }\end{array}$ \\
\hline 5. & & $\begin{array}{l}\text { Baki, untuk } \\
\text { menghidangkan } \\
\text { air minum }\end{array}$ & $\begin{array}{l}\mathrm{P}=35 \\
\mathrm{~L}=25 \\
\mathrm{~T}=6\end{array}$ & $\begin{array}{l}\text { Cat impra } \\
\text { warna natural } \\
\text { top coat clear } \\
\text { gloss dan } \\
\text { doop }\end{array}$ & $\begin{array}{l}\text { A } \\
\text { Motif } \\
\text { bunga } \\
\text { kundur } \\
\text { B } \\
\text { Motif daun } \\
\text { sirih }\end{array}$ \\
\hline 6. & & $\begin{array}{l}\text { Tempat } \\
\text { Perhiasan }\end{array}$ & $\begin{array}{l}\mathrm{P}=10 \\
\mathrm{~L}=10 \\
\mathrm{~T}=6\end{array}$ & $\begin{array}{l}\text { Cat impra } \\
\text { warna tea } \\
\text { brown top } \\
\text { coat clear } \\
\text { gloss dan } \\
\text { doop }\end{array}$ & $\begin{array}{l}\text { Tidak ada } \\
\text { menerapkan } \\
\text { ragam hias }\end{array}$ \\
\hline 7. & & $\begin{array}{l}\text { Mangkok Tempat } \\
\text { Buah }\end{array}$ & $\begin{array}{l}\text { Oval } \\
\mathrm{P}=35 \\
\mathrm{~L}=25 \\
\mathrm{~T}=6\end{array}$ & $\begin{array}{l}\text { Cat impra } \\
\text { warna natural } \\
\text { top coat clear } \\
\text { gloss dan } \\
\text { doop }\end{array}$ & $\begin{array}{l}\text { Tidak ada } \\
\text { menerapkan } \\
\text { ragam hias }\end{array}$ \\
\hline & & $\begin{array}{l}\text { Tempat Koran } \\
\text { Dan Majalah }\end{array}$ & $\begin{array}{l}\mathrm{P}=45 \\
\mathrm{~L}=20 \\
\mathrm{~T}=35\end{array}$ & $\begin{array}{l}\text { Cat impra } \\
\text { warna natural } \\
\text { top coat clear } \\
\text { gloss dan } \\
\text { doop }\end{array}$ & $\begin{array}{l}\text { Tidak ada } \\
\text { menerapkan } \\
\text { ragam hias }\end{array}$ \\
\hline
\end{tabular}




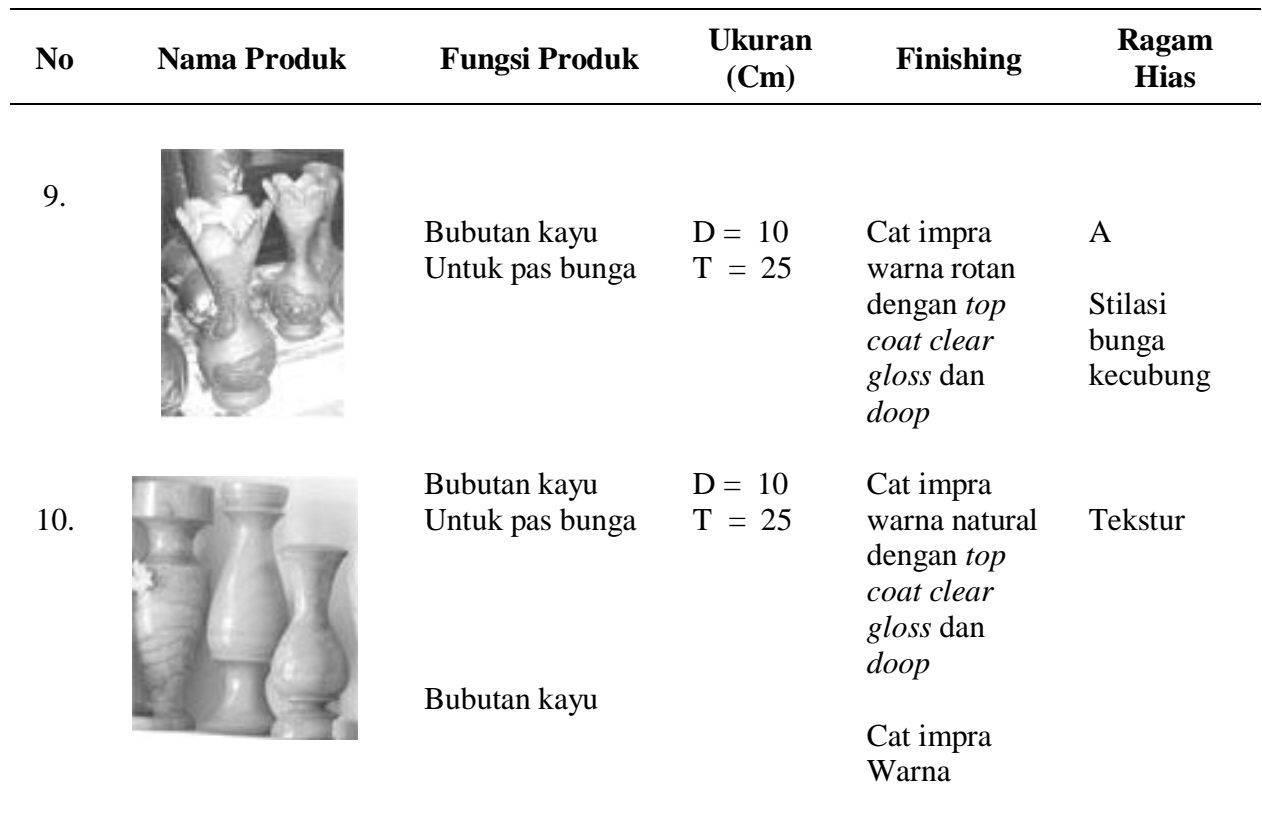

Tabel 2 Spesifikasi Jenis Produk Cinderamata.

\begin{tabular}{|c|c|c|c|c|c|}
\hline No & Nama Produk & Fungsi Produk & $\begin{array}{c}\begin{array}{c}\text { Ukuran } \\
(\mathrm{Cm})\end{array} \\
\end{array}$ & Finishing & Ragam Hias \\
\hline 11. & & $\begin{array}{l}\text { Benda hiasan di } \\
\text { atas meja kerja }\end{array}$ & $\begin{aligned} \mathrm{P} & =15 \\
\mathrm{~L} & =5 \\
\mathrm{~T} & =20 \\
\mathrm{t} & =1,2\end{aligned}$ & $\begin{array}{l}\text { Cat impra } \\
\text { warna rotan } \\
\text { dengan top } \\
\text { coat clear } \\
\text { gloss dan } \\
\text { doop }\end{array}$ & $\begin{array}{l}\text { A. } \\
\text { Selembayung } \\
\text { B. Roda gigi } \\
\text { C. Logo PLN }\end{array}$ \\
\hline 12. & & $\begin{array}{l}\text { Benda hiasan yang } \\
\text { berfungsi sebagai } \\
\text { tempat pena }\end{array}$ & $\begin{aligned} \mathrm{P} & =15 \\
\mathrm{~L} & =5 \\
\mathrm{~T} & =25 \\
\mathrm{t} & =1,2\end{aligned}$ & $\begin{array}{l}\text { Cat impra } \\
\text { warna rotan } \\
\text { dengan toop } \\
\text { coat clear } \\
\text { gloss dan } \\
\text { doop }\end{array}$ & $\begin{array}{l}\text { A. } \\
\text { Selembayung } \\
\text { dua balam } \\
\text { stenegger } \\
\text { B. } \\
\text { Lebah } \\
\text { bergantung }\end{array}$ \\
\hline 13. & & $\begin{array}{l}\text { Benda hiasan yang } \\
\text { berfungsi sebagai } \\
\text { tempat pena }\end{array}$ & $\begin{array}{l}\mathrm{P}=10 \\
\mathrm{~L}=5 \\
\mathrm{~T}=15\end{array}$ & $\begin{array}{l}\text { Cat impra } \\
\text { warna rotan } \\
\text { dengan toop } \\
\text { coat clear } \\
\text { gloss dan } \\
\text { doop }\end{array}$ & $\begin{array}{l}\text { Layar } \\
\text { Lancang } \\
\text { Kuning }\end{array}$ \\
\hline
\end{tabular}




\begin{tabular}{|c|c|c|c|c|c|}
\hline No & Nama Produk & Fungsi Produk & $\begin{array}{c}\text { Ukuran } \\
(\mathbf{C m})\end{array}$ & Finishing & Ragam Hias \\
\hline 14. & & Benda hiasan & $\begin{array}{l}P=45 \\
L=5\end{array}$ & $\begin{array}{l}\text { Cat akrilik } \\
\text { dengan toop } \\
\text { coat clear } \\
\text { gloss dan } \\
\text { doop }\end{array}$ & $\begin{array}{l}\text { Bagian haluan } \\
\text { diberi hias } \\
\text { selembanyung }\end{array}$ \\
\hline 15. & & Benda Hias & $\begin{array}{c}P=50 \\
D=20 \\
t=2\end{array}$ & Pelitur & $\begin{array}{l}\text { Kaligrafi } \\
\text { Arab }\end{array}$ \\
\hline 16. & & Asbak Rokok & $\begin{aligned} \mathrm{P} & =20 \\
\mathrm{~L} & =20 \\
\mathrm{t} & =3\end{aligned}$ & Teak wood & $\begin{array}{l}\text { Kaluk paku } \\
\text { dan Bunga } \\
\text { matahri }\end{array}$ \\
\hline 17. & & Tempat Pena & $\begin{array}{l}\mathrm{P}=15 \\
\mathrm{~L}=5 \\
\mathrm{~T}=20\end{array}$ & $\begin{array}{l}\text { Cat impra } \\
\text { warna tea } \\
\text { brown dengan } \\
\text { top coat clear } \\
\text { gloss dan } \\
\text { doop }\end{array}$ & $\begin{array}{l}\text { Candi } \\
\quad \text { Muara } \\
\quad \text { Takus } \\
\text { Rumah } \\
\text { Lontik [7] }\end{array}$ \\
\hline 18. & & Tatakan Al-Qur'an & $\begin{array}{l}\mathrm{P}=35 \\
\mathrm{~L}=20 \\
\mathrm{t}=2.5\end{array}$ & $\begin{array}{l}\text { Cat akrilik } \\
\text { dengan tekni } \\
\text { sungging }\end{array}$ & $\begin{array}{l}\text { Kaluk Paku } \\
\text { danTampuk } \\
\text { Manggis }\end{array}$ \\
\hline 19 & & Hias dinding & $\begin{array}{l}\mathrm{P}=45 \\
\mathrm{~L}=25 \\
\mathrm{t}=3\end{array}$ & $\begin{array}{l}\text { Cat akrilik } \\
\text { dan cat impra }\end{array}$ & $\begin{array}{l}\text { Motif } \\
\text { kelopak } \\
\text { jambu air } \\
\text { Dipadukan } \\
\text { dengan pucuk } \\
\text { rebung }\end{array}$ \\
\hline
\end{tabular}




\subsection{Segi Bentuk Produk Kerajinan Kayu}

Produk kerajinan yang menjadi objek utama pada penelitian ini adalah produk wadah untuk keperluan upacara adat. Produk wadah sebagaimana yang telah disebutkan terdiri dari: tepak sirih, tabak, kotak serbaguna dan baki, namun yang akan dianalisis dalam penelitian ini adalah produk tepak sirih dan tabak yang digunakan sebagai wadah untuk keperluan upacara adat.

Tujuan melakukan analisa tersebut di atas adalah untuk melihat kekurangan dan kelebihan dari masing-masing produk yang dihasilkan sebagai bahan masukan atau pertimbangan untuk perajin dalam membuat produk dimasa yang akan datang. Adapun aspek-aspek yang akan dianalisa meliputi aspek bentuk, aspek material dan aspek fungsi. Dari ketiga aspek tersebut, akan dilihat apakah ada aspek yang dapat mengangkat citra daerah. Untuk melakukan analisa produk kerajinan kayu dalam kaitan ini digunakan akan diuraikan sebagai berikut yaitu:

\subsubsection{Tepak Sirih}

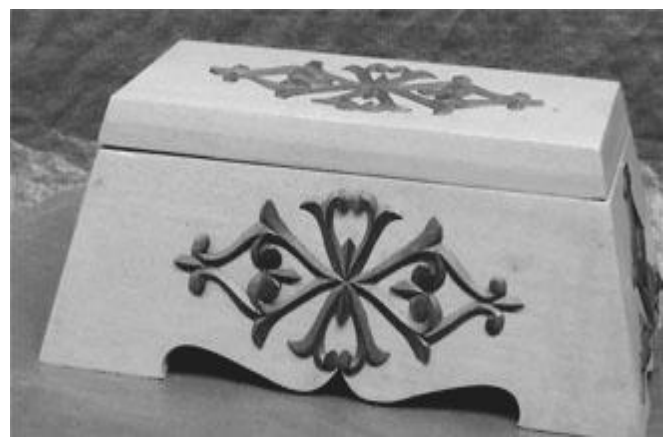

1) Bentuk

Secara visual bentuk tepak sirih yang dibuat oleh perajin pada saat ini masih berpedoman pada bentuk produk yang lama yaitu bentuk trapesium, dengan ukuran bagian atas $14 \mathrm{~cm}$ x $24 \mathrm{~cm}$ dan bagian bawah $24 \mathrm{~cm}$ x $30 \mathrm{~cm}$ dengan tinggi $15 \mathrm{~cm}$. Namun jika mengacu pada ukuran tepak sirih peninggalan kerajaan Siak, ukuran tersebut tidak proporsional terutama pada ukuran kemiringan. Ukuran kemiringan tepak peninggal raja Siak $2: 5$. Sedangkan tepak yang ada sekarang ini $3: 5$. Mengingat tepak sirih produk budaya yang perlu dilestarikan keberadaanya maka dalam membuatnya harus mengikuti ketentuan terutama berpedoman dari produk yang telah ada. Bentuk trapesium merupakan bentuk segi-empat dimana bagian bawah lebih lebar dari pada bagian atas sehingga kuat untuk menahan beban dari atas. Bentuk tersebut memberikan pengertian kekuatan dan keseimbangan kepada masyarakat Melayu. Kekuatan dalam hal ini diekspresikan dengan bidang lebar bagian 
bawah, yang merupakan bagian masyarakat Melayu secara luas. Sedangkan bagian atas memiliki bidang yang lebih kecil dari pada bagian bawah jika diperpanjang akan membentuk bidang runcing. Hal ini memberi pengertian bahwa dengan dasar persatuan yang kuat akan mencapai tujuan yang dicitacitakan. Cita-cita tersebut adalah persahabatan dan kedamaian yang menghasilkan persatuan yang kuat.

Bidang lengkung bagian bawah dimaksudkan untuk memperindah tampilan produk, dalam hal ini justru menimbulkan kesan yang kurang sopan. Jika diamati secara teliti dan seksama bidang lengkung tersebut membentuk seperti posisi orang yang sedang jongkok, sehingga memberikan kesan negatif terhadap penilaian sebuah produk budaya. Oleh karena itu dalam pembuatan produk yang akan datang bidang lengkung tersebut harus dihilang, jika tetap menggunakan bidang tersebut harus dibuat dengan bentuk yang mengambil motif kubah.

\section{2) Material}

Untuk membuat produk tepak sirih digunakan kayu jelutung. Dalam ilmu bahan bangunan kayu jelutung/kayu pulai termasuk jenis kayu lunak dan ringan sehingga tidak tahan terhadap serangan rayap dan cepat lapuk. Mengingat masa pemakaian produk ini cukup lama, maka bahan baku yang digunakan harus dipilih dari kayu yang keras dan tahan terhadap serangan rayap seperti, kayu balam, kayu sungkai dan kayu rengas. Jenis kayu tersebut memiliki tekstur serat dan warna kayu yang bagus. Dalam pembuatan sebuah produk bahan harus menjadi pertimbangan utama, sebab bahan juga merupakan suatu pertimbangan konsumen untuk membeli sebuah produk. Pertimbangan inilah kiranya yang harus menjadi perhatian pengrajin untuk beralih dari menggunakan kayu jelutung / kayu lunak ke kayu yang keras.

\section{3) Fungsi}

Secara adat tradisi fungsi tepak sirih tidak mengalami perubahan yaitu sebagai tempat daun risih, gambir, pinang dan kacip. Kacip adalah sejenis gunting yang digunakan untuk mengupas buah pinang. Dalam masyarakat Melayu Riau fungsi tepak sirih secara simbolik mengandung makna keterbukaan, ramah, dan mau menerima siapa saja tanpa memandang suku bangsa dan agama. Berdasarkan fungsi produk sebagai pewadahan untuk keperluan upacara adat di masyarakat Melayu Riau, dalam hal ini mengindikasikan bahwa tradisi kebudayaan yang diwariskan dari lehulur masih tumbuh dan dijunjung tinggi oleh masyarakat pendukungnya.

Dari perjalanan waktu ke waktu tepak sirih selain sebagai benda wadah untuk keperluan adat, kini tepak sirih digunakan sebagai cinderamata bagi wisatawan ataupun tamu pemerintah daerah yang berkunjung ke Pekanbaru. Sebagai 
produk cinderamata, tepak sirih dalam hal ini baik fungsi, maupun makna simbolik ragam hias yang diterapkan tidak mengalami perubahan dalam arti tetap sebagai produk wadah untuk keperluan upacara adat. Dari hasil keterangan tersebut dapat diambil suatu kesimpulan bahwa produk tepak sirih dalam fungsinya sebagai cinderamata memiliki misi sebagai media untuk mempromosikan hasil budaya daerah terutama, ragam hias tradisional Melayu Riau kepada masyarakat secara luas. Selain sebagai media pomosi, tepak sirih memiliki nilai komersial, dalam arti produk tersebut kini bukan saja berfungsi sebagai perlengkapan upacara adat untuk menyambut tamu tetapi secara komersial telah dijadikan sebagai benda cinderamata khas Pekanbaru.

\subsubsection{Tabak}

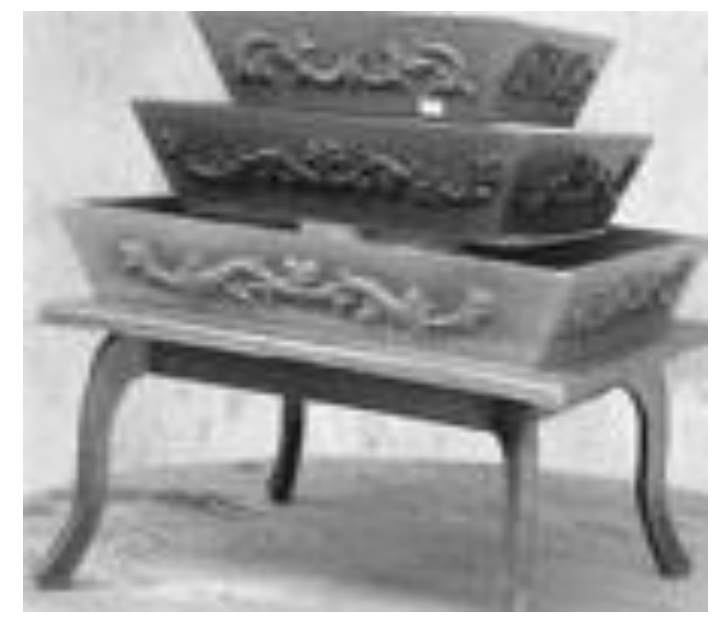

1) Bentuk

Bentuk tabak amat bervariasi, namun secara umum berbentuk trapesium yaitu besar bagian bawah dan semakin keata semakin mengecil. Tabak terdiri dari tiga bagian yaitu atas, tengah dan bawah dengan ukuran berbeda-beda. Tiga bagian tersebut melambangkan tiga kehidupan yaitu kehidupan di dunia, kehidupan di alam kubur dan kehidupan di alam akhirat. Tiga tingkatan kehidupan tersebut merupakan penggambaran dan sekaligus sebagai nasehat bagi masyarakat Melayu Riau agar selalu ingat kepada Allah. Bentuk tabak tersebut jika dikaitkan dengan fungsinya sebagai tempat nasi kuning yang diberi hiasan telur dan bunga kertas yang dijadikan hiasan pada alat pelaminan, sangat mendukung dan sesuai. Sesuai dalam hal ini terkait dengan nasehat adanya tiga kehidupan yang dapat mengingatkan kedua penganting harus selalu patuh dan taat menjalankan perintah Allah. 


\section{2) Material}

Penggunaan material pada setiap produk akan berpengaruh terhadap hasil akhir. Semakin baik material yang digunakan semakin baik kualitas produk yang dihasilkan. Demikian juga dengan penggunaan material untuk membuat Tabak. Mengingat kegunaan tabak sebagai wadah untuk nasi kuning yang cukup berat, untuk itu tabak harus dibuat dari bahan kayu yang kuat dan tahan terhadap beban sehingga usia pemakaiannya tabak dapat bertahan lama.

Kenyataan ini sangat berbeda dengan kondisi tabak yang ada sekarang. Tabak dibuat dari bahan kayu campuran yaitu, untuk lantai digunakan papan meranti tebal $2,5 \mathrm{~cm}$ tetapi untuk kotak diatasnya dibuat dari kayu jelutung dengan alas dibawahnya triplek $3 \mathrm{~mm}$. Sifat triplek tidak tahan terhadap air, sedangkan kayu jelutung tidak tahan terhadap rayap. Dari uraian diatas dapat disimpulkan bahwa penggunaan material pada produk tabak didasarkan pada harga bahan yang murah dan mudah dalam pengerjaan tanpa, mempertimbangkan kekutan dan usia pemakaian produk, dengan kata lain penggunaan material untuk tabak didasarkan pada kebutuhan komersial untuk memperoleh keuntungan yang sebesar-besarnya.

\section{3) Fungsi}

Tabak adalah produk wadah yang digunakan untuk tempat nasi kuning yang di atasnya diberi hiasan telur dan bunga kertas dengan berbagai warna. Tabak dalam masyarakat Melayu Riau berfungsi sebagai elemen dekorasi pada perangkat pelaminan. Tabak diletakkan didepan sebelah kanan bawah atau dilantai tepat didepan penganting bersanding. Fungsi tabak sampai saat ini belum mengalami perubahan dalam arti masih tetap digunakan sebagai tempat nasi kuning pada acara adat perkawinan di masyarakat Melayu.

Dari uraian di atas dapat disimpulkan bahwa fungsi tabak sebagai unsur dekorasi pada pelaminan memikili peran yang sangat penting, dalam arti sebagai media untuk menyampaikan pesan dan nasehat kepada kedua pengantin, jika merujuk pada tiga tingkatan dari bentuk tabak yang memiliki arti tiga kehidupan.

\section{Peran Ragam Hias Pada Produk Tepak Sirih dan Tabak}

Sebagai industri kerajinan kayu yang dipercaya untuk membuat produk kerajinan khas Riau dalam membuat produk kerajinan, perajin Sentra Melayu Riau Souvenir selalu menerapkan ragam hias tradisional sebagai elemen dekorasi produk. 
Berdasarkan hasil pengamatan di lapangan, peran ragam hias tradisional Melayu pada produk kerajinan kayu dalam konteks ini pada prinsipnya bertujuan untuk meningkatkan nilai keindahan pada produk dalam rangka meningkatkan volume penjualan. Namun yang lebih penting dari penerapan ragam hias tradisional pada produk tepak sirih dan tabak adalah untuk memberikan makna simbolik sesuai dengan fungsinya sebagai pewadahan untuk keperluan upacara adat.

\subsection{Peran Ragam Hias Sebagai Identitas Budaya Daerah}

Untuk melakukan analisa peran ragam hias pada produk kerajinan kayu, sebagai identitas budaya, mengacu pada makna simbolik ragam hias tradisional Melayu, dengan cara mengkorelasikan peran ragam hias pada produk kerajinan kayu yang ada, sehingga diketahui apakah ragam hias yang diterapkan pada produk sesuai atau tidak. sehingga dapat digunakan sebagai pedoman pembuatan produk dimasa mendatang.

Peran ragam hias sebagai identitas budaya, memiliki nilai implisit (simbolik) yang ada hubungannya dengan pandangan hidup dari masyarakat,. Nilai tersebut mengacu pada sifat-sifat asal dari setiap benda atau makluk yang dijadikan motif yang dipadukan dengan nilai-nilai luhur dalam agama Islam. Oleh karena itu penempatan ragam hias harus berpedoman pada nilai simbolik ragam hias dan kegunaan produk, dengan demikian dalam penerapannya harus mengikuti pattern (pola) yang ada, terutama hubungan antara makna simbolik ragam hias tradisional dengan produk kerajinan yang dibuat. Karena penempatan ragam hias yang tidak sesuai dengan produk yang akan diberi dekorasi, akan mengurangi nilai secara inplisit pada produk itu sendiri. Contoh, produk tepak sirih sebagai hasil produk budaya masyarakat Melayu Riau yang digunakan untuk tempat daun sirih, gambir, pinang dan gunting untuk dipersembahkan kepada tamu pada rangkaian upacara adat tradisi dalam penyambutan tamu, akan berubah maknanya secara implisit jika pada produk tersebut ditempakan ragam hias naga berjuang [8].

Berdasarkan hasil pengamatan di lapangan, ragam hias yang selalu diterapkan pada produk kerajinan kayu untuk jenis produk wadah untuk keperluan upacara adat pada saat ini, sebagian besar menggunakan ragam hias yang bersumber dari flora, seperti ragam hias kaluk paku, ragam hias bunga cengkeh dan ragam hias bunga kundur. Ragam hias tersebut merupakan ragam hias tradisional Melayu Riau yang diadopsi dari jenis flora yang ada di Propinsi Riau.

Dari analisa yang dilakukan terhadap produk yang dijadikan obyek dalam penelitian ini, penempatan ragam hias pada produk tepak sirih dan tabak sudah sesuai dengan kandungan makna simbolik, yang dianggap telah mencerminkan 
salah satu identitas budaya Melayu Riau. Tetapi jika mengacu pada produk tepak sirih peninggalan kerajaan Siak, berdasarkan nilai estetis keindahan pada produk penerapan ragam hias masih sangat jauh dari yang diharapkan. Oleh karena itu untuk pembuatan produk yang akan datang perlu dilakukan pemilihan ragam hias yang lebih kreatif sehingga menghasilkan produk yang berkualitas dan memiliki makna yang relevan antara ragam hias dan fungsi produk.

Tabel 3 Makna Simbolik Ragam Hias Pada Produk Kerajinan.

\begin{tabular}{|c|c|c|c|c|c|c|}
\hline \multirow{2}{*}{ No } & \multirow{2}{*}{ Jenis Produk } & \multicolumn{5}{|c|}{ Peran Ragam Hias Sebagai Identitas Budaya } \\
\hline & & Peran/Tujuan & Kelompok & Nama & Asal & Simbol \\
\hline 1. & $\begin{array}{l}\text { Tepak Sirih } \\
\text { Ukuran } \\
\text { Produk } \\
\text { Panjang : } \\
\text { 30/24 } \\
\text { Lebar : 24/14 } \\
\text { Tinggi : 15 } \\
\text { Fungsi : } \\
\text { Sebagai } \\
\text { tempat sirih } \\
\text { Material : } \\
\text { Kayu jelutung } \\
\text { Teknik } \\
\text { pengerjaan } \\
\text { 1. Kerja } \\
\text { bangku } \\
\text { 2. Ukiran } \\
\text { langsung } \\
\text { 3. Ukiran } \\
\text { tempel } \\
\text { Pasar: } \\
\text { 1. Harga Rp } \\
\text { 45.000,- } \\
\text { 2. Untuk } \\
\text { pasar } \\
\text { regional } \\
\text { Animo } \\
\text { Masyarakat } \\
\text { Penggunaan } \\
\text { tepak sirih }\end{array}$ & $\begin{array}{l}\text { Sebagai Unsur } \\
\text { Dekorasi } \\
\text { produk yang } \\
\text { memiliki makna } \\
\text { simbolik }\end{array}$ & $\begin{array}{l}\text { Flora } \\
\text { Jenis } \\
\text { kuntum } \\
\text { bunga }\end{array}$ & $\begin{array}{l}\text { Bunga } \\
\text { cengkeh }\end{array}$ & $\begin{array}{l}\text { Melayu } \\
\text { Riau } \\
\text { diadopsi } \\
\text { dari motif } \\
\text { bunga } \\
\text { cengkeh }\end{array}$ & $\begin{array}{l}\text { - Motif } \\
\text { Sebagai simbol } \\
\text { kasih sayang, } \\
\text { kecucian, } \\
\text { persahabatan, } \\
\text { ketulusan, } \\
\text { kehalusan budi } \\
\text { pekerti dan } \\
\text { kelembutan hati } \\
\text { Melihat } \\
\text { penggunaan } \\
\text { tepak sirih untuk } \\
\text { upacara adat } \\
\text { merupakan } \\
\text { simbol dari sikap } \\
\text { ramah tamah, } \\
\text { mau menerima } \\
\text { siapa saja, sikap } \\
\text { terbuka, dan } \\
\text { menjaga } \\
\text { persahabatan } \\
\text { maka,makna } \\
\text { simbolik motif } \\
\text { bunga cengkeh } \\
\text { yang diterapkan } \\
\text { dapat, } \\
\text { mendukung } \\
\text { penggunaan } \\
\text { tepak sirih. } \\
\text { • Warna dasar } \\
\text { Coklat sebagai } \\
\text { simbol tanah } \\
\text { yang memiliki } \\
\text { makna } \\
\text { kesuburan, }\end{array}$ \\
\hline
\end{tabular}




\begin{tabular}{|c|c|c|c|c|c|c|}
\hline \multirow{2}{*}{ No } & \multirow{2}{*}{ Jenis Produk } & \multicolumn{5}{|c|}{ Peran Ragam Hias Sebagai Identitas Budaya } \\
\hline & & Peran/Tujuan & Kelompok & Nama & Asal & Simbol \\
\hline & $\begin{array}{l}\text { sebagai } \\
\text { wadah untuk } \\
\text { keperluan } \\
\text { upacara adat, } \\
\text { mendapat } \\
\text { sambutan dari } \\
\text { masyarakat } \\
\text { sangat bagus. } \\
\text { Sementara } \\
\text { segmen juga } \\
\text { sangat bagus, } \\
\text { terbukti dari } \\
\text { data } \\
\text { penjualan } \\
\text { showroom } \\
\text { Dekranasda } \\
\text { Propinsi Riau, } \\
\text { didukung } \\
\text { dengan data- } \\
\text { data jenis } \\
\text { produk dari } \\
\text { industri. }\end{array}$ & & & & & $\begin{array}{l}\text { kemakmuran } \\
\text { Penggunaan } \\
\text { warna coklat } \\
\text { terkait dengan } \\
\text { kekayaan dan } \\
\text { kemakmuran } \\
\text { masyarakat } \\
\text { Melayu yang } \\
\text { diekspresikan } \\
\text { melalui upacara } \\
\text { adat. }\end{array}$ \\
\hline
\end{tabular}

Catatan:

Kelemahan

1. Penyusunan motif hiasan pada bagian sudut produk masih kosong sehingga terkesan minim ornament.

2. Desain bentuk motif tidak mengikuti bentuk dan ukuran produk, ini terlihat dari perbandingan panjang dan lebar motif Kayu yang digunkan mudah dimakan rayap/cepat lapuk.

Kelebihan

1. Penerapan motif sesuai dengan penggunaan tepak sirih sebagai wadah untuk untuk keperluan upacara adat

\begin{tabular}{|c|c|c|c|c|c|}
\hline $\begin{array}{l}\text { Tabak } \\
\text { Ukuran } \\
\text { Produk: } \\
\text { Panjang: } \\
\text { 20,25,30 cm } \\
\text { Lebar: } \\
\text { 20,25,30 cm }\end{array}$ & $\begin{array}{l}\text { Sebagai Unsur } \\
\text { Dekorasi } \\
\text { produk yang } \\
\text { memiliki makna } \\
\text { simbolik }\end{array}$ & $\begin{array}{l}\text { Flora } \\
\text { Jenis sulur }\end{array}$ & $\begin{array}{l}\text { Lilit } \\
\text { kangkung }\end{array}$ & $\begin{array}{l}\text { Melayu } \\
\text { Riau } \\
\text { diadopsi } \\
\text { dari } \\
\text { tumbuhan } \\
\text { kangkung. }\end{array}$ & $\begin{array}{l}\text { - Motif } \\
\text { Sebagai simbol } \\
\text { semangat dalam } \\
\text { menjalani hidup, } \\
\text { terus berjuang } \\
\text { pantang } \\
\text { menyerah. } \\
\text { Makna simbolik } \\
\text { dari motif ini } \\
\text { memberi pesan } \\
\text { bahwa hidup ini } \\
\text { banyak tantangan } \\
\text { dan rintangan }\end{array}$ \\
\hline
\end{tabular}




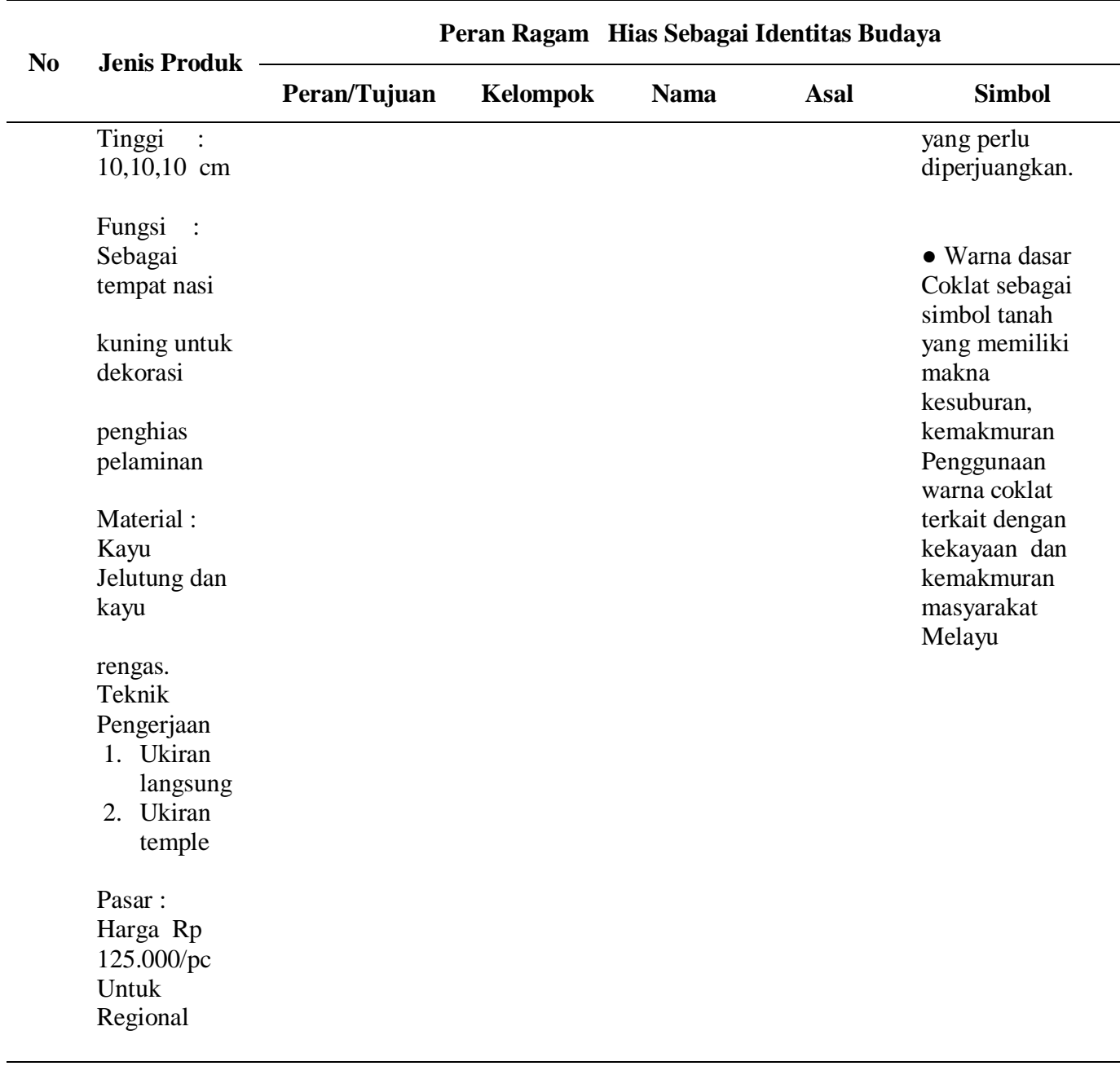

Catatan:

Kelemahan

- Penggunaan jenis ragam hias sebagai unsur dekorasi produk tabak, terlalu sederhana sehingga terkesan produk murahan

- Desain bentuk ragam hias tidak mengikuti bentuk dan ukuran produk, sehingga masih terdapat bidang kosong

- Kayu yang digunakan mudah dimakan rayap/cepat lapuk.

Kelebihan

- Ragam hias tidak variatif

- Penerapan ragam hias sesuai dengan penggunaan tabak sebagai penghias alat pelaminan

- Finishing menggunakan cat impra, sehingga produk tahan terhadap serangan rayap 


\subsection{Peran Ragam Hias Tradisional untuk Meningkatkan Volume Penjualan Produk Kerajinan}

Agar produk kerajinan yang dihasilkan Sentra Melayu Riau Souvenir memiliki keunggulan yang kompetitif sebagai modal utama dalam memasuki pasar diperlukan pemahaman secara menyeluruh dari semua aspek yang dapat menunjang terciptanya produk kerajinan yang unggul. Diantanya adalah dengan cara mengembangkan gagasan karya, yaitu mencari kemungkinan alternatif pola penempatan, olah bentuk dan olah warna ragam hias produk kerajinan yang dapat diterima pasar sebagai produk potensial.

Kemungkinan alternatif yang dapat dilakukan dalam rangka menghasilkan produk kerajinan yang unggul satu diantaranya adalah dengan memanfaatkan ragam hias tradisional sebagai dekorasi produk. Dalam konteks ini ragam hias tradisional dimanfaatkan sebagai sumber kreatifitas untuk menghasilkan produk kerajinan yang bervariatif (diversifikasi) sehingga, konsumen akan memiliki banyak pilihan terhadap produk yang diinginkan Diversifikasi produk kerajinan dilakukan mengingat kemungkinan adanya kejenuhan dari konsumen terhadap produk kerajinan yang ditawarkan, sehingga berdampak pada daya beli. Diversifikasi dapat berupa produk baru ataupun produk lama dengan cara dimodifikasi ragam hias, material dan bentuk.

Dalam melakukan diversifikasi produk kerajinan untuk meningkatkan volume penjualan, banyak cara yang dapat dilakukan oleh perajinan Sentra Melayu Riau Souvenir. Adapun cara atau langkah-langkah untuk melakukan diversifikasi terhadap hasil produk kerajinan Sentra Melayu Riau Souvenir pada saat ini yaitu, melakukan olah penempatan ragam hias, olah bentuk ragam hias dan olah pewarnaan/finishing.

\section{Kesimpulan}

Sentra Melayu Riau Souvenir merupakan industri kerajinan kayu di Pekanbaru yang memproduksi benda wadah untuk keperluan upacara adat seperti tepak sirih dan tabak. Dalam menjalankan usaha sebagai perajin yang memproduksi benda pewadahan, Sentra Melayu Riau Souvenir mengalami berbagai permasalahan terkait dengan pengetahuan tentang peran ragam hias sebagai unsur dekorasi pada produk. Namun demikian berdasarkan hasil analisa yang dilakukan pada produk tepak sirih dan tabak dapat disimpulan sebagai berikut:

Dari produk pewadahan untuk keperluan upacara adat ternyata penempatan ragam hias memiliki makna simbolik yang dapat mendukung fungsi ataupun kegunaan produk, artinya makna simbolik ragam hias yang terdapat pada produk pewadahan memiliki makna simbolik yang sama dengan ragam hias 
yang terdapat pada produk pewadahan hasil peningglan kerajaan Siak. Dengan demikian ragam hias yang ditempatkan pada produk tepak sirih dan tabak yang ada sekarang ini dapat digunakan sebagai unsur dekorasi yang memiliki makna simbolik.

Peran ragam hias tradisional Melayu Riau dalam rangka meningkatkan jumlah varians produk pewadahan untuk keperluan upacara adat, belum dimanfaatkan secara optimal oleh perajin yang ada di Pekanbaru. Hal ini dapat dilihat dari jumlah produk pewadahan yang yang ada sekarang ini, memiliki kesamaan ragam hias dengan jenis produk yang lain, artinya satu jenis ragam hias digunakan untuk menghias beberapa jenis produk

Dapat disimpulkan bahwa ragam hias sebagai sumber kreatifitas bagi perajin untuk menghasilkan varian produk dalam rangka meningkatan volume penjualan produk belum dimanfaatkan secara optimal, hal ini disebabkan oleh beberapa faktor antara lain: peran lembaga pendidikan yang lebih berkompeten dalam pelestarian budaya daerah, belum menyentuh sampai ke perajin sehingga perbendaharaan perajin terhadap jenis ragam hias tradisional Melayu yang ditempatkan pada produk kerajinan kayu sangat sedikit.

\section{Daftar Pustaka}

[1] Yudoseputro,Wiyoso. 1983. Seni Kerajinan Indonesia, Proyek Pengadaan Buku Dirjendikdasmen Depdikbud.

[2] Selamat Isa, Muhammad. 2001. Gagasan Pembangunan \& Kekuatan Jatidiri: Riau Menuju Jalan Puncak, Pusat Kajian Warisan Melayu Riau, Bengkalis.

[3] Marizar, Eddy S.. 2005. Designing Furniture: Teknik Merancang Mebel Kreatif, Media Pressindo, Yogyakarta.

[4] Yusuf, Yusmar. 1996. Gaya Riau Sentuhan Fenomenologis Budaya Melayu di Tengah Globalisasi, Pusat Pengkajian Bahasa Dan Kebudayaan Melayu, Universitas Riau, Pekanbaru.

[5] Ghalib, Wan. 1991. Umar, Said Mahmud dan Kadir, Moh. Daud, Adat Istiadat Melayu Riau Di Bekas Kerajaan Siak Sri Inderapura, Lembaga Adat Daerah Riau Pemerintah Daerah Tingkat I Propinsi Riau, Pekanbaru.

[6] Hasan, Bachtiar. 2002. Manajemen Industri, Pustaka Ramadhan, Bandung.

[7] Dekranasda Propinsi Riau. 2005. Data Hasil Penjualan Cinderamata.

[8] Malik, Abdul. 2003. Corak dan Ragi Tenun Melayu Riau, Adicita Karya Nusa, Yogyakarta. 